\title{
Corporate boards' and firms' R\&D responses to performance feedback
}

Michal Jirásek

Department of Corporate Economy,

Faculty of Economics and Administration, Masaryk University, Brno, Czech Republic

\section{Abstract}

Purpose - A firm will respond to performance feedback, i.e. a comparison of its current performance with the goals to which it aspires, by means of changes in its search activity. There is an emerging body of literature that studies how such behavioral responses are shaped by important decision-makers inside firms. The study focuses on the corporate board - one of the most influential decision-making groups in terms of strategy. More specifically, the study aims to study the moderation effect of the size, turnover and age diversity of the board. Design/methodology/approach - The sample is based on the largest listed German automobile and manufacturing firms followed between the years 2001 and 2015. The sample is analyzed using fixed-effects panel data models.

Findings - The findings indicate that the age diversity of the corporate board and, partially, also the turnover of its members moderate firms' responsiveness to performance feedback. On the other hand, the size of the board does not seem to play a role. The study, therefore, supports the notion of taking into account the characteristics of the corporate board when analyzing strategic decision-making and points to areas for further research.

Originality/value - The study contributes to the literature by empirically testing the moderating effect of three characteristics of corporate boards that have not been largely tested in the literature to date.

Keywords R\&D, Performance feedback, Corporate boards, German industrial firms

Paper type Research paper

\section{Introduction}

There are numerous factors that cause firms to change strategy. One of the major drivers identified in the literature is performance feedback (Posen et al., 2018), i.e. a comparison of a firm's actual performance and the performance goals to which it aspires. Based on Simon's (1955) concept of bounded rationality, when a firm does not attain the goals to which it aspires, it is likely to search for behavioral alternatives. In this case, a process called problemistic search begins (Cyert and March, 1963) with the aim of finding new solutions for bridging the problematic gap between negative performance and aspiration. In the opposite case, where the firm's aspirations are exceeded, the new slack resources enable it to loosen budgetary restrictions and also to search for new strategic alternatives.

However, the firm is far from a monolithic decision-making subject. It consists of various groups of stakeholders that shape its decisions. One of the principal strategic decisionmaking groups is the corporate board. Since Desai's (2016) study on the effect of the composition of the board on firms' responses to performance feedback, there has been

(C) Michal Jirásek. Published by Emerald Publishing Limited. This article is published under the Creative Commons Attribution (CC BY 4.0) licence. Anyone may reproduce, distribute, translate and create derivative works of this article (for both commercial and non-commercial purposes), subject to full attribution to the original publication and authors. The full terms of this licence may be seen at http:// creativecommons.org/licences/by/4.0/legalcode

To be added after the review process.

The research was supported by the Masaryk University research project MUNI/A/1262/2020 Behavior of organizations and their stakeholders.

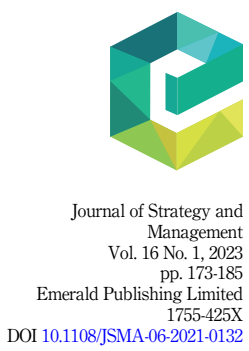


JSMA

16,1

174

relatively little research examining the role of the board (Choi et al., 2019; Zhang and Greve, 2019; Zhong et al., 2021). This study represents an important contribution to this subject and the literature on performance feedback, as it sheds some light on the role of the firm's internal composition in its behavior. Studies of the influence of various stakeholders and their characteristics are still scarce and largely missing in the literature (Kolev and McNamara, 2020). Understanding the interplay between various groups of stakeholders brings new insight into the firm's decision-making (Posen et al., 2018). Furthermore, it also strengthens the connection of empirical research and the theory behind performance feedback as the theory builds on interactions among various stakeholders and their goals (Cyert and March, 1963).

This paper contributes to this subject by studying the moderating role of three board characteristics: size, turnover and diversity. The first two effects were proposed and tested in Desai (2016). However, since Desai's work was later retracted, the existing literature now lacks an empirical test of the influence of board turnover characteristics (board size has been only recently tested in Zhong et al., 2021). The third effect, board age diversity, represents a novel extension of the literature. In general, board diversity interferes with a firm's strategic change (e.g. Goodstein et al., 1994), which makes it an important characteristic in the study of the board's influence on a firm's responsiveness to performance feedback. Overall, this paper contributes to the growing body of research on the subject of the role of various groups of decision-makers on the responsiveness of firms to performance feedback (e.g. Kolev and McNamara, 2020).

\section{Theory and hypotheses}

Performance feedback and search

The behavioral theory of the firm (Cyert and March, 1963) presumes that the firm is a boundedly rational economic actor. This means that it does not attempt to maximize its performance but rather strives to attain certain performance goals or aspirations. When its aspirations are not met, i.e. there is a performance problem, a process called problemistic search is initiated. In problemistic search, the firm attempts to find alternative courses of action that will enable it to achieve its future aspirations. There is a wealth of empirical studies that have observed changes in both search activity of firms and their actual strategies that were based on the receipt of negative performance feedback (for reviews, see Greve, 2003; Shinkle, 2012; Posen et al., 2018; Kotiloglu et al., 2021). Most of them indicate that firms increase their search activity after experiencing negative attainment discrepancy between their actual performance and their aspirations (e.g. Chen and Miller, 2007; Lucas et al., 2018).

On the other hand, when aspirations are met or exceeded (i.e. there is positive attainment discrepancy), a problemistic search is not initiated. However, Cyert and March (1963) proposed an alternative driver of search - slack resources. Slack resources are the difference between available resources and the resources that are required to keep the firm running. They generally provide a cushion during bad times, when they can be used without limiting the normal functioning of the firm. More importantly for the firm's search activity, this cushion can be used to experiment and search for new ideas, which would, otherwise, be too risky. Positive attainment discrepancy is a source of new slack resources, as the performance difference represents an inflow of unexpected (and, therefore, not yet required) resources. This should lead to an increase in the search activity of the firm when it has exceeded its aspirations (e.g. Chen and Miller, 2007).

H1a. There is a negative relationship between negative attainment discrepancy (between performance and aspiration) and the search activity of firms.

H1b. There is a positive relationship between positive attainment discrepancy (between performance and aspiration) and the search activity of firms. 
The board's influence on the firm's responses to performance feedback

The corporate board plays an important role in formulating the strategy of the firm (Hillman and Dalziel, 2003). It is, therefore, not surprising that the board and its characteristics are also linked to the performance of firms (e.g. Erhardt et al., 2003; Cheng, 2008). In general, the observed relationship between a firm's board and its performance calls for further attention to the role of the board in the behavior of firms. As I summarize below, various compositions of boards (in terms of size, turnover and age diversity) may influence the responsiveness of firms to performance feedback.

Desai (2016) was the first to integrate the role of boards in responses to performance feedback. He focused on the moderation effects of board characteristics (size, turnover and equity ownership) on service line divestitures among Californian for-profit hospitals experiencing negative attainment discrepancy. However, due to coding errors, the study was later retracted. In a different study, Choi et al. (2019) focused on the moderating role of board (and managerial) outsiderness for both negative and positive attainment discrepancy among Korean manufacturing firms. They found support for an effect of the board role in the case of negative attainment discrepancy, where firms with more outside board members reacted more strongly to performance feedback [in this case, increasing Research and Development (R\&D) intensity]. A third study on this newly emerging topic was by Zhang and Greve (2019), who studied how board composition (the proportion of members with state or market experience) in listed Chinese firms affected their acquisition choices. They found that boards with a high proportion of members with state experience greatly diminished the effect of performance feedback on the probability of market-oriented acquisitions. In contrast to the previous study, they found the most important effects for firms that had experienced positive attainment discrepancy (except for acquisition funding, where both types of attainment discrepancy played a role). Finally, a study by Zhong et al. (2021) focused on how negative attainment discrepancy influences corporate social responsibility and irresponsibility practices. As for the role of boards, they focused on three characteristics: size, age and tenure. They find that all three characteristics moderate firm corporate social responsibility responses to negative attainment discrepancy. On the other hand, only tenure moderates irresponsibility behavior.

While the number of studies on this subject remains limited, it appears that boards do play a role in the way firms respond to performance feedback and that they affect such decisions when a firm's performance is both below and above its aspirations.

Board size. If the size of the board is large, the number of members in the group may make it relatively more difficult to reach a consensus. As evident from the studies below, large boards tend to incline toward less intensive reactions. Therefore, they avoid more radical changes that smaller boards would conduct.

While it may be that it is the board diversity that mainly constrain strategic decisionmaking (e.g. Midavaine et al., 2016), size also plays a role (Goodstein et al., 1994). When consensus is achieved, it is likely to be much less extreme, as it needs to accommodate a large number of members and will naturally gravitate toward the status quo. Cheng (2008) found that larger boards do play such a stabilizing role, both in performance (market- and accounting-based) and strategic activities (such as R\&D spending, acquisitions or restructuring). This would imply that the larger the firm's board, the lower its responsiveness to performance feedback. The interpretation of performance feedback (and opinions on future courses of action) may not be only different among the board's members, but also there may be too many of them to find the necessary support for more extreme courses of action.

The decreased responsiveness to performance feedback should apply to situations of both negative and positive attainment discrepancy: Large boards do not prefer large changes in firm reactions to performance feedback. Thus, situational components of search (problemistic

Boards and firms' R\&D responses 
JSMA

16,1

and slack search, Chen and Miller, 2007) play a smaller role in such firms. Thus, firms with large boards are more prudent with changing the current status quo (as it is harder for them to decide on changes) and also find it harder to find directions in which to search, thus limiting their willingness to invest resources into situational search. Therefore, I hypothesize as follows:

H2a. Board size negatively moderates the relationship between negative attainment discrepancy and the search activity of firms.

$H 2 b$. Board size negatively moderates the relationship between positive attainment discrepancy and the search activity of firms.

Board turnover. While it takes time for new board members to fully develop their potential for the firm, with long tenures the quality of their decision-making decreases (Huang and Hilary, 2018). Zhong, Ren and Song (2021) argue that boards with longer tenures tend to be more short-sighted and thus less inclined to invest in long-term value creation. Similarly, while the level of the board's outsiderness is an important characteristic that influences responsiveness to performance feedback (Choi et al., 2019), Dalton et al. (2007) surmise that the effect is likely to vanish over time. This is in line with the suggestion of Dalton et al. (2007) that board members (especially internal ones) appointed during the tenure of the current Chief Executive Officer (CEO) may exhibit loyalty to her or him. This effect is likely to be strongest soon after the appointment. Higher board turnover prevents outside board members from accommodating the firm's internal politics. To a certain extent, the same is arguably true for internal board members.

Board turnover thus seems an important precursor for the freshness of ideas and willingness to support search for strategic alternatives stimulated by performance feedback. For example, Goodstein and Boeker (1991) argue that new board members may bring in new ideas and, therefore, challenge the status quo (the firm's inertia). Therefore, I expect that increased turnover may increase the willingness to search for alternatives and decrease opposition toward changing the status quo. In this respect, both situation components of search (problemistic and slack search) should be pronounced with increasing board turnover. I hypothesize as follows:

H3a. Board turnover positively moderates the relationship between negative attainment discrepancy and the search activity of firms.

H3b. Board turnover positively moderates the relationship between positive attainment discrepancy and the search activity of firms.

Board age diversity. Generally, diverse boards should discuss a wider range of strategic alternatives. Homogenous groups tend to experience stronger pressures toward uniformity of voice, thereby increasing the risk of being subject to groupthink (Janis, 1971). Haynes and Hillman (2010) propose that general board diversity is one of two components of overall board capital (Hillman and Dalziel, 2003), i.e. its breadth. Haynes and Hillman (2010) show that, in contrast to board capital depth, higher board capital breadth leads to a higher level of strategic change. If firms with more diverse boards are more prone to commit to change, they are more open to responding to the stimuli of both negative and positive attainment discrepancy by increasing their search activity.

On the other hand, as Goodstein et al. (1994) argue, diversity within a group may constrain the board's ability to take decisive action. In this case, it is important to distinguish between a firm's search for alternative courses of action (this research) and its ultimate commitment to them. When looking at how Haynes and Hillman (2010) operationalized the strategic change, we can see that they followed a set of resource allocations [advertising, R\&D, selling, general and administrative (SG\&A), inventory, plant equipment upgrades and financial leverage] as 
they varied over time and in how they deviated from industry norms. This is very different from a set of ultimate decisions such as service additions, divestitures or reorganizations (which were studied by Goodstein et al., 1994). Therefore, diverse boards may support a wider search for alternatives (which is likely to come up with quite diverse visions of the firm's future development), yet they may face difficulties in choosing from this array of opportunities.

There are a number of dimensions on which one can measure diversity. For example, Harjoto et al. (2015) work with seven of them: gender, race, age, outside directorship, tenure, power and expertise. Still, even such an extensive list is far from complete. Gender and age diversities belong to the popular choices for diversity measures (Kang et al., 2007). On the other hand, despite an increase in initiatives supporting more gender-diverse boards, in many countries, boards are quite homogeneous in terms of gender (e.g. Janošová et al., 2016). While age diversity is also limited as there is not a large share of young board members, the situation is better (Kang et al., 2007). For this reason, the study follows board age diversity.

Based on the argument above, I hypothesize that boards with higher age diversity should embrace more search activities stemming from reactions to performance feedback:

H4a. Board age diversity positively moderates the relationship between negative attainment discrepancy and the search activity of firms.

H4b. Board age diversity positively moderates the relationship between positive attainment discrepancy and the search activity of firms.

Figure 1 summarizes the hypothesized relationships.

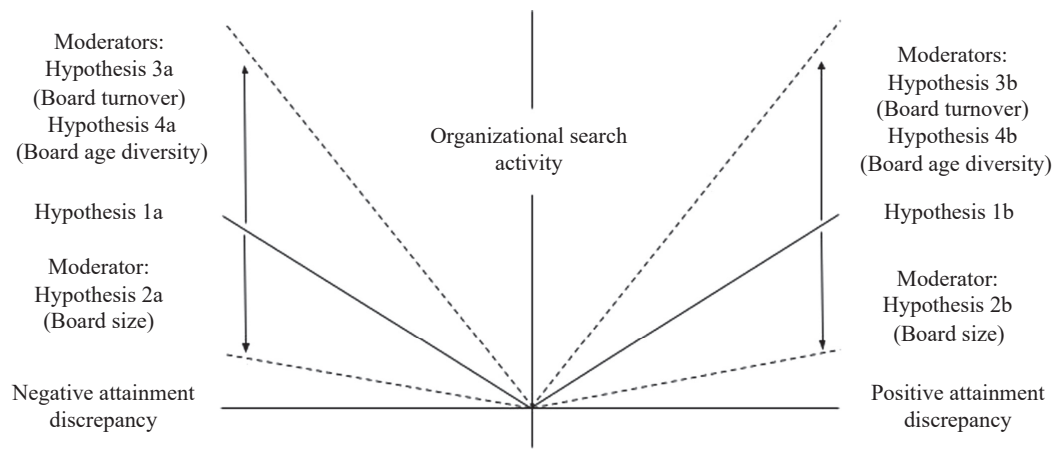

Figure 1. Hypothesized relationships

\section{Methodology}

\section{Sample}

The population of the study consists of the 60 largest exchange-listed German industrial and automobile firms followed between the years 2001 and 2015. The industry classification is based on the Bloomberg Industry Classification System. The ranking of the size of firms is based on market capitalization as at the end of July 2016. The study limits the population to the largest firms, since boards tend to be smaller in smaller firms. While the mean board size for the ten largest firms in the population is 7.28 , it is only 2.44 for the smallest ten. Any further decrease would make the board characteristics used in this study (size, turnover and age diversity) meaningless. The source of the firms' financial data is the Bloomberg database and the data on boards were collected from the firms' annual reports, investor relations sections of their websites or other industry sources.

Due to missing data (mainly on the dependent variable), the final sample consisted of 41 firms. Even so, there were still some observations missing, for example, because a firm had 
JSMA

16,1 not existed for the whole of the research period. The final sample used represents an unbalanced panel with 363 firm year observations.

\section{Variables}

Dependent variable. The research utilizes R\&D intensity change as the dependent variable, which is calculated as the year-on-year change in the ratio of R\&D expenditure to sales. R\&D is a common measure of the search activity of manufacturing firms in performance feedback literature (Greve, 2003; Posen et al., 2018).

Attainment discrepancy - performance feedback variables. The research uses return on assets (ROA) as a performance measure. Although criticized in the field (Bromiley and Harris, 2014), it is still the most commonly used measure in performance feedback literature (Kotiloglu et al., 2021) and is a salient performance measure used by various decision-makers. The performance feedback literature works with two major aspects of a firm's aspiration the historical (based on the firm's previous performance) and the social (based on the performance of the firm's peers). Since the empirical identification of a peer group is a complicated and rather simplifying process (most often, the mean or median of other firms in the same industry has been used, e.g. in Lucas et al., 2018, which may not be very realistic), I decided to work only with historical aspirations (specifically, the previous year's performance). Attainment discrepancy is then operationalized as the difference between the firm's current and previous year's ROA. Finally, I divide attainment discrepancy into two variables: (1) negative attainment discrepancy (in which I keep the negative values of attainment discrepancy and replace the positive values with zeros) and (2) positive attainment discrepancy (in which I keep the positive values and substitute the negative values with zeros). This is a standard approach in the literature (Posen et al., 2018; Kotiloglu et al., 2021) and allows for the observation of different responses to negative and positive attainment discrepancy. Both variables are lagged by one year as firms need time to react to the information contained in performance feedback they received. One-year lag is commonly used in the performance feedback literature concerning R\&D responses (e.g. Lucas et al., 2018).

Board characteristics. Board size is operationalized as the number of board members in a given year. Board turnover is calculated as the sum of newly appointed and leaving members divided by the sum of current (newly appointed plus staying) and leaving members. Board age diversity is the variance of the age of all board members in a given year, which is divided by 100 . For similar reasons as those mentioned above, all board variables are lagged by one year.

Controls. As slack resources may provide a cushion for the firm (Cyert and March, 1963), they may influence the firm's responsiveness to performance feedback stimuli. I control for the effect of slack resources using available slack (operationalized as current assets to current liabilities) and potential slack (operationalized as debt to equity). As previous research shows (e.g. Chen and Miller, 2007), firms that are threatened by bankruptcy respond differently to performance feedback. For this reason, I control for proximity to bankruptcy with Altman's Z. I also include a logarithm of the firm's total assets to account for the effect of firm size. Again, all these controls are lagged by one year. Since R\&D intensity change may be the result of a change in sales (e.g. decreased sales with constant R\&D expenditure will cause R\&D intensity to increase), I also add a variable measuring change in sales. Finally, I control for general year-on-year differences using year dummies.

\section{Estimation}

To deal with outliers, all variables have been winsorized at four standard deviations below and above the mean. This affected a maximum of $3 \%$ of firm year observations (in several 
variables) across the dataset. Due to the nature of the hypotheses, which focus on within (firm) variance of responses, fixed-effects models are preferable to random-effects (Certo et al., 2017). This is also statistically supported by Hausman tests. Furthermore, using fixed-effects models allowed controlling for time-invariant firm- (and thus industry-) level heterogeneity in the dependent variable. I used heteroskedasticity and autocorrelation consistent (HAC) robust estimations to provide more robust estimates of standard errors that may be otherwise biased. I calculated models using Stata 15. Table 1 displays the descriptive statistics and correlations for the sample.

\section{Results}

Table 2 includes the calculated models for the search activity of firms. Model 1 includes only controls. Model 2 adds attainment discrepancy variables, with negative attainment discrepancy positive and significant ( $\phi$-value $=0.028$ ), which contradicts Hypothesis 1 a. The coefficient for positive attainment discrepancy is not significant, which provides no support for Hypothesis 1b. Model 3 adds board characteristics variables, none of which are significant at this stage.

Model 4 tests the moderation effect of board size on the relationship between attainment discrepancy and the search activity of firms. However, neither of the two moderation coefficients is significant, which provides no support for hypotheses $2 \mathrm{a}$ and $2 \mathrm{~b}$ (see Figure 1 ).

Model 5 tests the moderation effect of board turnover. In this model, the negative attainment discrepancy coefficient is no longer significant and neither is the moderation effect of board turnover ( $p$-value $=0.209$ ), which does not support Hypothesis $3 a$. On the other hand, the coefficient of positive attainment discrepancy is positive and significant $(p$-value $=0.038)$, and the moderation effect of board turnover is negative and significant $(\phi$-value $=0.022)$, which contradicts Hypothesis 3b. Figure 2 depicts the moderation effect of board turnover on the relationship between positive attainment discrepancy and the search activity of firms. With increasing positive attainment, firms with no board turnover increase their search intensity discrepancy in a similar way to firms with the mean level of board turnover. However, in the latter case, the increase is much smaller. In contrast, firms with a high level of turnover (one standard deviation above the mean) show decreasing search activity, as their positive attainment discrepancy increases.

Model 6 tests the moderation effect of board age diversity. Again, the coefficient for negative attainment discrepancy is positive but not significant $(\phi$-value $=0.141)$. On the other hand, the moderation effect of board age diversity for it is negative and significant $(p$-value $=0.022)$, which supports Hypothesis 4a. Figure 3 depicts the moderation effect of board age diversity on the relationship between negative attainment discrepancy and the search activity of firms. Firms with no age diversity have decreasing search intensity the higher the negative attainment discrepancy they experience, which is similar to firms with the mean level of board age diversity. However, in the latter case, the decrease is much smaller. In contrast, firms with a high level of age diversity (one standard deviation above the mean) show increasing search activity, as negative attainment discrepancy increases.

At the same time, the coefficient of positive attainment discrepancy is not significant, while the moderation effect of board age diversity is positive and significant $(\phi$-value $=0.012)$, which provides support for Hypothesis $4 \mathrm{~b}$. Figure 4 depicts the moderation effect of board age diversity on the relationship between positive attainment discrepancy and the search activity of firms. Firms with no age diversity have slightly decreasing search intensity the higher the positive attainment discrepancy they experience. In contrast, firms with the mean and high levels of age diversity (one standard deviation above the mean) show increasing search activity, as positive attainment discrepancy increases. 
JSMA

16,1

180

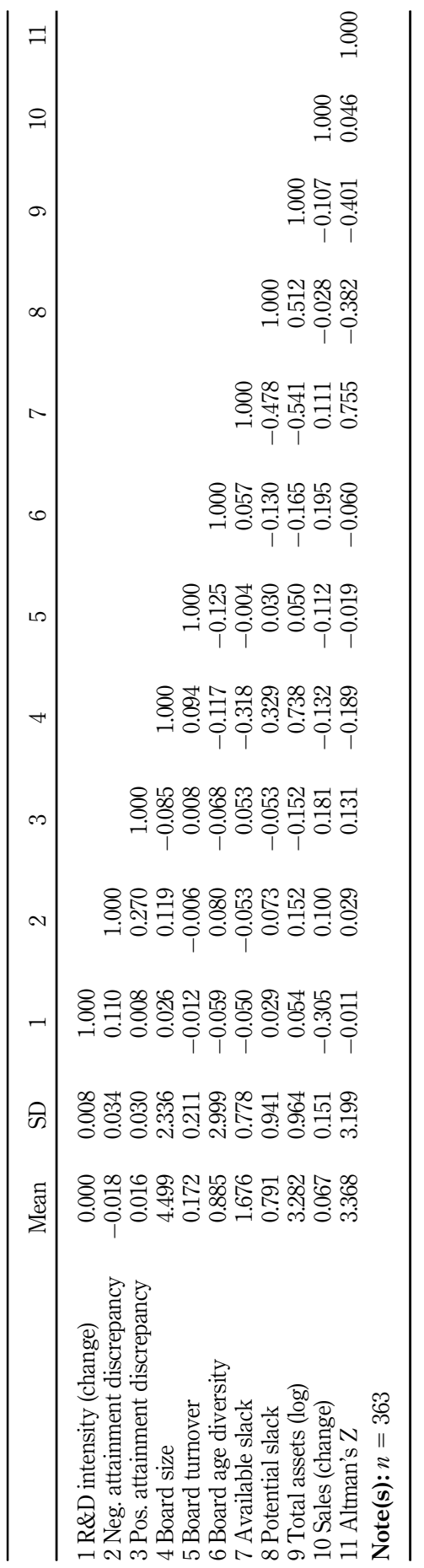

Table 1.

Descriptive statistics and correlations 


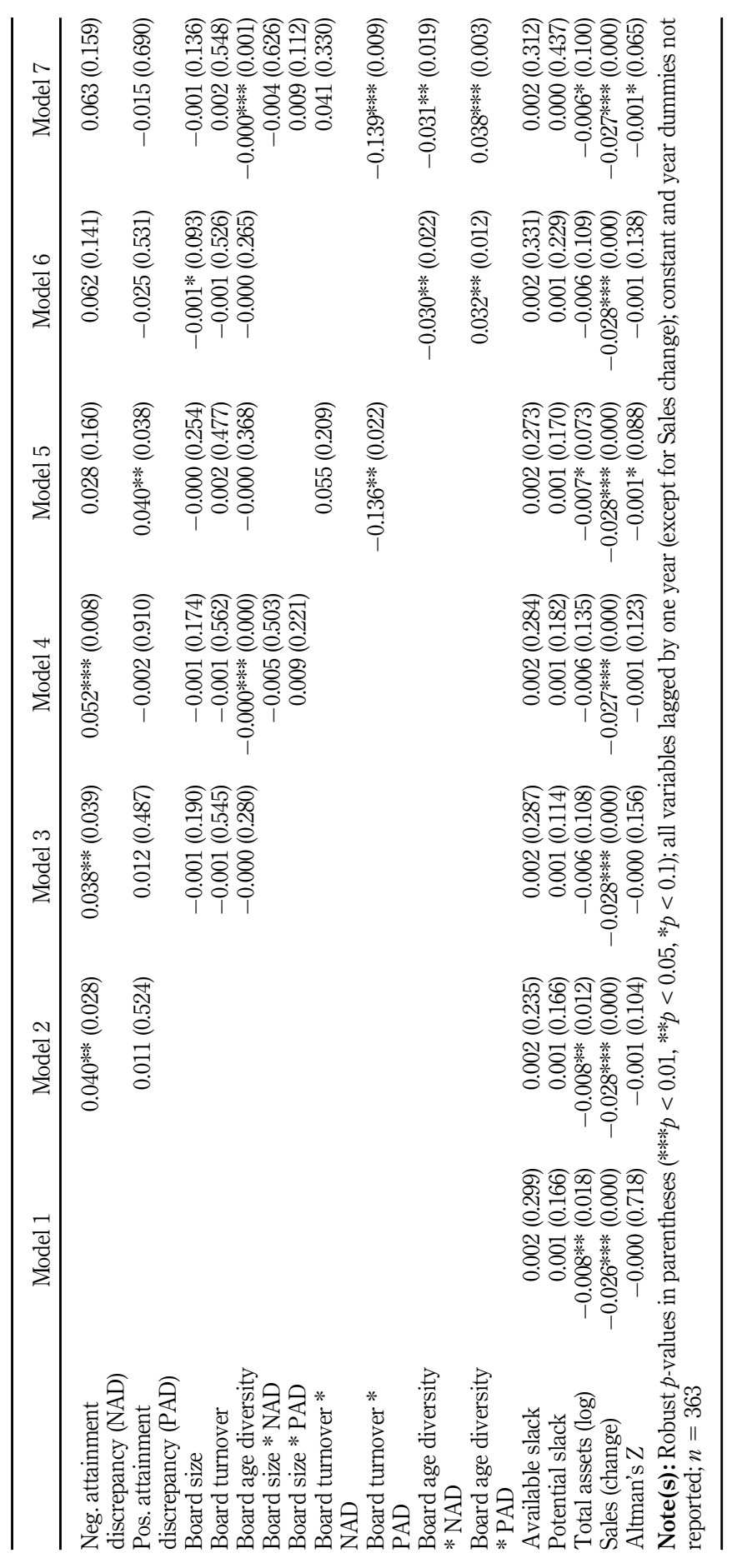

Boards and firms' R\&D responses

181

Table 2.

Models for the search activity of firms (R\&D intensity change) 
JSMA

16,1

\section{2}

Figure 2.

Moderation effect of board turnover on the relationship between positive attainment discrepancy and the search activity of firms (Model 5)
0.025

0.020

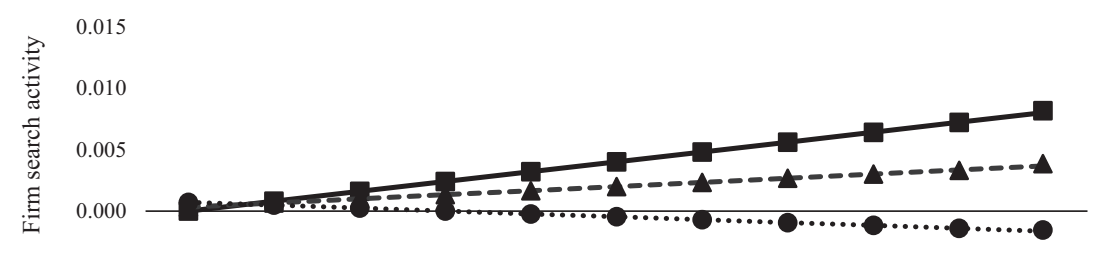

$-0.005$

$-0.010$ $\begin{array}{lllllllllll}0.00 & 0.02 & 0.04 & 0.06 & 0.08 & 0.10 & 0.12 & 0.14 & 0.16 & 0.18 & 0.20\end{array}$ Positive attainment discrepancy

$\longrightarrow$ No turnover $(=0.00) \quad-\infty-\cdot$ Mean turnover $(=0.17) \quad \cdots \cdot \cdots$ High turnover $(=0.38)$

\subsection{5}

0.020

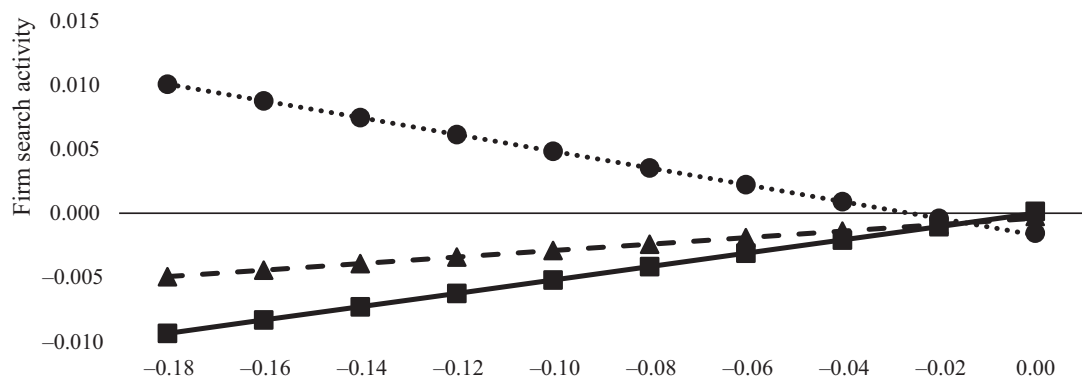

Negative attainment discrepancy

$\longrightarrow$ No age diversity $(=0.00) \quad-\quad$ Mean age diversity $(=0.89) \quad \cdots \cdot \cdots$ High age diversity $(=3.88)$

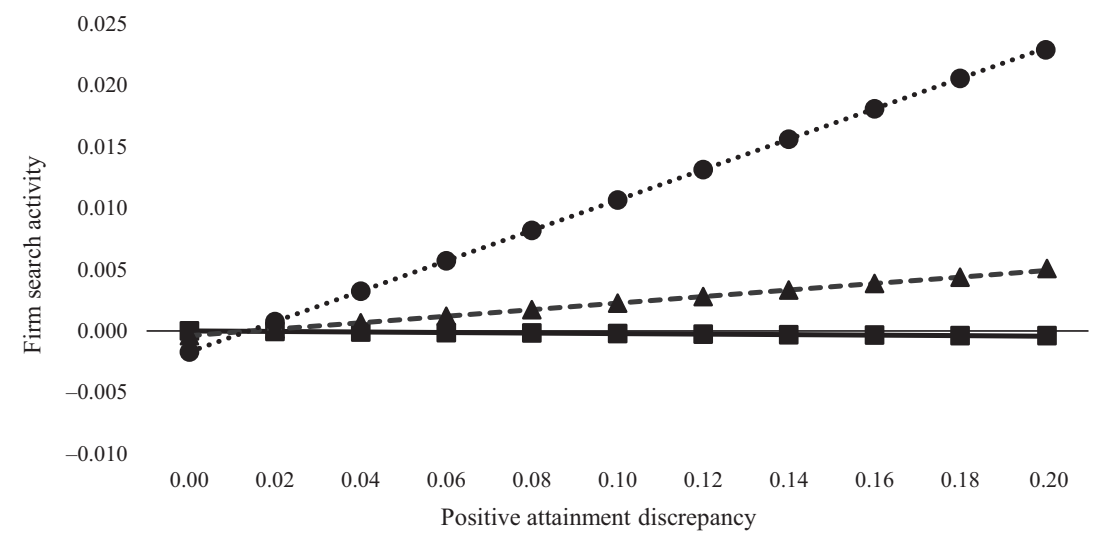

No age diversity $(=0.00) \quad-\quad-\infty$ Mean age diversity $(=0.89) \quad \cdots \cdot \cdots$ High age diversity $(=3.88)$ 
Finally, Model 6 includes all the moderation variables at the same time. The results of this combined model reflect those that were already reported, which support hypotheses $4 \mathrm{a}$ and $4 \mathrm{~b}$ and contradict Hypothesis 3b (Hypothesis 1a is not directly contradicted).

\section{Discussion}

The findings indicate that, of the three board characteristics in this study, board age diversity plays the strongest moderating role in responsiveness to performance feedback. Age diversity substantially increases the level of responsiveness for both negative and positive attainment discrepancy. These findings should not be directly interpreted in the sense that more diverse boards are more prone to change. There may be a difference between their willingness to search for alternative courses of action (which is studied in this paper and in the related research of Haynes and Hillman, 2010 and Choi et al., 2019) and their willingness to, ultimately, commit to strategic change (which was studied by Goodstein et al., 1994 and Zeng and Greve, 2018). This idea may be summarized as follows: diversity may foster creativity but inhibit innovation (the implementation of creative ideas). Since the relationship between age diversity and both of these concepts is still unclear (Rietzschel and Zacher, 2015), it may be an interesting avenue for future research.

In contrast to the hypothesized relationship, board turnover tends to reduce the responsiveness of firms to positive attainment discrepancy. This is in line with Desai's (2016) propositions. It seems that with higher turnover, the board concentrates on the further exploitation of currently successful strategies rather than investing in the search for new ones.

As for board size, this study does not provide any evidence of its effect on the responsiveness of firms to performance feedback (to either negative or positive attainment discrepancy). One possible explanation, which relates to the argument of Goodstein et al. (1994), is that the effect of board size is largely based on the growing diversity of the board. Since this study controls for one of the aspects of board diversity (the age diversity of its members), it may more directly capture what board size implies. On the other hand, it is the diversity of opinions and the quantity of them that most likely creates situations where it is difficult to reach a consensus. As with the argument related to board age diversity, board size may not affect the search activity of the firm but may affect the ultimate decisions that result from it.

It is also worth noting that the general response to negative attainment discrepancy across the sample contradicts predictions of the theory (Cyert and March, 1963). More specifically, firms in the sample decreased their search activity after receiving negative performance feedback. Although it contradicts the theory, this paper is not the first study to report such a finding (e.g. Posen et al.,2018). In this case, it was likely caused by the specificity of the sample - either in terms of the size of the firms (the 60 largest German industrial firms) or the cultural specifics of German firms (the boards of these firms are highly homogeneous in terms of nationality). This is certainly a possible avenue for further research.

The research shows that the moderation effects of board characteristics should be studied both in terms of negative and positive attainment discrepancy (as in Zhang and Greve, 2019; or Choi et al., 2019). Firms with different levels of board age diversity (and, to some extent, board turnover) exhibit very different behaviors. This is a probable explanation of the inconsistent findings of both negative and positive attainment discrepancy across the models.

I believe that this study can motivate further research on the diversity characteristics of boards. The outsiderness of board members (Choi et al., 2019), the length of their tenure (as suggested by Dalton et al., 2007) and classical demographic characteristics (gender, age and nationality) may all reflect opinion diversity on boards, which may or may not constrain or 
JSMA

16,1

boost a firm's responsiveness to performance feedback. Unfortunately, listed German manufacturing firms do not constitute a very heterogeneous population in various aspects (e.g. gender and nationality, Janošová et al., 2016), which has limited this research into this area.

\section{Conclusion}

This research supports the notion that the responses of firms to performance feedback in terms of their search activity are shaped by their internal composition. The findings highlight the role of board age diversity as an important moderator of the responsiveness of firms to performance feedback (both negative and positive attainment discrepancy). Similarly, board turnover was found to moderate responses to positive attainment discrepancy. The research points to a wide range of opportunities to further explore the effects of the firm's principal decision-makers on its responsiveness to performance feedback.

\section{References}

Bromiley, P. and Harris, J.D. (2014), "A comparison of alternative measures of organizational aspirations”, Strategic Management Journal, Vol. 35 No. 3, pp. 338-357.

Certo, T.S., Semadeni, M.C. and Withers, M. (2017), "A tale of two effects: using longitudinal data to compare within- and between-firm effects", Strategic Management Journal, Vol. 38 No. 7, pp. 1536-1556.

Chen, W.-R. and Miller, K.D. (2007), "Situational and institutional determinants of firms' R\&D search intensity”, Strategic Management Journal, Vol. 28 No. 4, pp. 369-381.

Cheng, S. (2008), "Board size and the variability of corporate performance", Journal of Financial Economics, Vol. 87 No. 1, pp. 157-176.

Choi, J., Rhee, M. and Kim, Y.-C. (2019), "Performance feedback and problemistic search: the moderating effects of managerial and board outsiderness", Journal of Business Research, Vol. 102, pp. 21-33.

Cyert, R.M. and March, J.G. (1963), A Behavioral Theory of the Firm, Prentice Hall/Pearson Education, Upper Saddle River.

Dalton, D.R., Hitt, M.A., Certo, S.T. and Dalton, C.M. (2007), "The fundamental agency problem and its mitigation", Academy of Management Annals, Vol. 1 No. 1, pp. 1-64.

Desai, V.M. (2016), "The behavioral theory of the (governed) firm: corporate board influences on organizations' responses to performance shortfalls", Academy of Management Journal, Vol. 59 No. 3, pp. 860-879.

Erhardt, N.L., Werbel, J.D. and Shrader, C.B. (2003), "Board of director diversity and firm financial performance”, Corporate Governance: An International Review, Vol. 11 No. 2, pp. 102-111.

Goodstein, J. and Boeker, W. (1991), "Turbulence at the top: a new perspective on governance structure changes and strategic change", Academy of Management Journal, Vol. 34 No. 2, pp. 306-330.

Goodstein, J., Gautam, K. and Boeker, W. (1994), "The effects of board size and diversity on strategic change", Strategic Management Journal, Vol. 15 No. 3, pp. 241-250.

Greve, H.R. (2003), Organizational Learning from Performance Feedback: A Behavioral Perspective on Innovation and Change, Cambridge University Press, Cambridge.

Harjoto, M., Laksmana, I. and Lee, R. (2015), "Board diversity and corporate social responsibility", Journal of Business Ethics, Vol. 132 No. 4, pp. 641-660.

Haynes, K.T. and Hillman, A. (2010), "The effect of board capital and CEO power on strategic change", Strategic Management Journal, Vol. 31 No. 11, pp. 1145-1163. 
Hillman, A.J. and Dalziel, T. (2003), "Boards of directors and firm performance: integrating agency and resource dependence perspectives", Academy of Management Review, Vol. 28 No. 3, pp. 383-396.

Huang, S. and Hilary, G. (2018), "Zombie board: board tenure and firm performance", Journal of Accounting Research, Vol. 56 No. 4, pp. 1285-1329.

Janis, I.L. (1971), “Groupthink”, Psychology Today, Vol. 5 No. 6, pp. 43-46.

Janošová, L., Jirásek, M. and Pirožek, P. (2016), "Diversity of Czech and German corporate boards experience from MNC's", in Pinzaru, F. and Bratianu, C. (Eds), Proceedings of the 12th European Conference on Management Leadership and Governance. Academic Conferences and Publishing International, Budapest, pp. 109-115.

Kang, H., Cheng, M. and Gray, S.J. (2007), "Corporate governance and board composition: diversity and independence of Australian boards", Corporate Governance: An International Review, Vol. 15 No. 2, pp. 194-207.

Kolev, K.D. and McNamara, G. (2020), "The role of top management teams in firm responses to performance shortfalls", Strategic Organization, Online first.

Kotiloglu, S., Chen, Y. and Lechler, T. (2021), "Organizational responses to performance feedback: a meta-analytic review”, Strategic Organization, Vol. 19, pp. 285-311.

Lucas, G.J.M., Knoben, J. and Meeus, M.T.H. (2018), "Contradictory yet coherent? Inconsistency in performance feedback and R\&D investment change", Journal of Management, Vol. 44 No. 2, pp. 658-681.

Midavaine, J., Dolfsma, W. and Aalbers, R. (2016), "Board diversity and R\&D investment", Management Decision, Vol. 54 No. 3, pp. 1-16.

Posen, H., Keil, T., Kim, S. and Meissner, F. (2018), "Renewing research on problemistic search: a review and research agenda", Academy of Management Annals, Vol. 12 No. 1, pp. 208-251.

Rietzschel, E.F. and Zacher, H. (2015), "Workplace creativity, innovation, and age", Encyclopedia of Geropsychology, Springer, New York.

Shinkle, G.A. (2012), "Organizational aspirations, reference points, and goals: building on the past and aiming for the future", Journal of Management, Vol. 38 No. 1, pp. 415-455.

Simon, H.A. (1955), “A behavioral model of rational choice”, Quarterly Journal of Economics, Vol. 69 No. 1, pp. 99-118.

Zhang, C.M. and Greve, H.R. (2019), "Dominant coalitions directing acquisitions: different decision makers, different decisions", Academy of Management Journal, Vol. 62 No. 1, pp. 44-65.

Zhong, X., Ren, L. and Song, T. (2021), "Beyond market strategies: how multiple decision-maker groups jointly influence underperforming firms' corporate social (ir)responsibility”, Journal of Business Ethics, Online first.

\section{Corresponding author}

Michal Jirásek can be contacted at: mijirasek@mail.muni.cz

For instructions on how to order reprints of this article, please visit our website:

www.emeraldgrouppublishing.com/licensing/reprints.htm

Or contact us for further details: permissions@emeraldinsight.com 